\title{
Bacillus rigui sp. nov., isolated from wetland fresh water
} Correspondence
Chi Nam Seong
scnu@scnu.ac.kr

\author{
Keun Sik Baik, ${ }^{1}$ Chae Hong Lim, ${ }^{1}$ Seong Chan Park, ${ }^{1}$ Eun Mi Kim, ${ }^{1,2}$ \\ Moon Soo Rhee ${ }^{3}$ and Chi Nam Seong ${ }^{1}$
}

\author{
${ }^{1}$ Department of Biology, Sunchon National University, Suncheon 540-742, Republic of Korea \\ ${ }^{2}$ Department of Dental Hygiene, Gwangju Health College University, Gwangju 506-701, Republic \\ of Korea \\ ${ }^{3}$ Biological Resource Center, Korea Research Institute of Bioscience and Biotechnology, 52 \\ Oun-dong, Yuseong, Daejeon 305-333, Republic of Korea
}

\begin{abstract}
Two Gram-stain-positive strains, WPCB074 ${ }^{\top}$ and WPCB165, were isolated from fresh water collected from the Woopo wetland (Republic of Korea). Both strains were strictly aerobic, motile, endospore-forming rods. Phylogenetic analysis based on 16S rRNA gene sequences indicated that strains WPCB074 ${ }^{\top}$ and WPCB165 belonged to the genus Bacillus and that strain WPCB074 ${ }^{\top}$ was most closely related to Bacillus solisalsi $\mathrm{YC}^{\top}{ }^{\top}$ (98.4 \% sequence similarity), $B$. barbaricus V2-BIII-A2 ${ }^{\top}$ (97.7\%), B. macauensis ZFHKF-1 ${ }^{\top}(96.9 \%)$, B. arsenicus Con $\mathrm{a} / 3^{\top}$ (96.4\%) and B. gelatini LMG $21880^{\top}(95.1 \%)$. The $16 \mathrm{~S}$ rRNA gene sequences of strains WPCB074 ${ }^{\top}$ and WPCB165 differed at one position (99.9\% similarity), suggesting that these two strains constitute a single species. DNA-DNA relatedness between strain WPCB074 ${ }^{\top}$ and the type strains of $B$. solisalsi, B. barbaricus, B. macauensis, B. arsenicus and B. gelatini were 26, $17,20,14$ and $7 \%$, respectively. Strain WPCB074 ${ }^{\top}$ was characterized by having cell-wall peptidoglycan based on meso-diaminopimelic acid, MK-7 as the predominant menaquinone and iso- $\mathrm{C}_{15: 0}$ and anteiso- $\mathrm{C}_{15: 0}$ as the major fatty acids. The DNA G+C content of strain WPCB074 ${ }^{\top}$ was $41.9 \mathrm{~mol} \%$. On the basis of phenotypic properties, phylogeny and genomic distinctiveness, strain WPCB074 ${ }^{\top}$ represents a novel species of the genus Bacillus for which the name Bacillus rigui sp. nov. is proposed. The type strain is WPCB074 ${ }^{\top}\left(=\right.$ KCTC $13278^{\top}=\mathrm{JCM}$ $\left.16348^{\top}\right)$.
\end{abstract}

Members of the genus Bacillus are widely distributed in nature and have physiologically diverse characteristics (Claus \& Berkeley, 1986). For a long time, most aerobic, endosporeforming rods were assigned to the genus Bacillus (Claus \& Berkeley, 1986). The results of genomic analyses proved that the genus Bacillus comprised heterogeneous taxa (Priest et al., 1981; Ash et al., 1991; Slepecky \& Hemphill, 1992; Stackebrandt \& Liesack, 1993; Nakamura, 1996). In particular, 16S rRNA gene sequence analyses have revealed the presence of several phylogenetically distinct lineages within the genus Bacillus. Consequently, some phylogenetic groups have been established as the following new genera: Alicyclobacillus (Wisotzkey et al., 1992), Alkalibacillus (Jeon

The GenBank/EMBL/DDBJ accession numbers for the 16S rRNA gene sequences of strains WPCB074 ${ }^{\top}$ and WPCB165 are EU939689 and EU939690.

DNA-DNA hybridization data for WPCB064 ${ }^{\top}$ and WPCB165 and related strains are available as supplementary material with the online version of this paper. et al., 2005), Aneurinibacillus (Shida et al., 1996), Brevibacillus (Shida et al., 1996), Marinibacillus (Yoon et al., 2001b), Paenibacillus (Ash et al., 1993), Pullulanibacillus (Hatayama et al., 2006), Salibacillus (Wainø et al., 1999), Sporolactobacillus (Hatayama et al., 2006), Ureibacillus (Fortina et al., 2001), Viridibacillus (Albert et al., 2007) and Virgibacillus (Heyndrickx et al., 1998). Also, several species of the genus Bacillus have been reclassified or transferred to the following genera: Geobacillus (Nazina et al., 2001), Gracilibacillus (Wainø et al., 1999), Lysinibacillus (Ahmed et al., 2007), Rummeliibacillus (Vaishampayan et al., 2009), Salimicrobium (Yoon et al., 2007) and Sporosarcina (Yoon et al., 2001a). Therefore, classification and identification of Gram-positive, endospore-forming rods should be performed by using a polyphasic taxonomic approach that integrates phylogenetic analysis based on 16S rRNA gene sequences, genomic relatedness and an extensive range of phenotypic characteristics (Shida et al., 1997a, b; Yoon et al., 1998; Tcherpakov et al., 1999). In the course of our study on wetland microbial diversity, two Gram-stain-positive, 
endospore-forming bacterial strains, designated strains WPCB $074^{\mathrm{T}}$ and WPCB165, were isolated from a fresh-water sample and were the subject of a taxonomic investigation.

Strains WPCB074 ${ }^{\mathrm{T}}$ and WPCB165 were isolated from a fresh-water sample collected from the wetland of Woopo $\left(35^{\circ} 33^{\prime} \mathrm{N} 128^{\circ} 25^{\prime} \mathrm{E}\right)$ located in the Republic of Korea using the standard dilution plating technique. Isolation was achieved using PYGV (Staley, 1968) and R2A agar (Oxoid) at $25{ }^{\circ} \mathrm{C}$ for 7 days. The isolates were routinely cultured on R2A agar and preserved at $-80{ }^{\circ} \mathrm{C}$ as a suspension in distilled water containing $20 \%(\mathrm{w} / \mathrm{v})$ glycerol.

Bacterial DNA preparation, PCR amplification and sequencing of the 16S rRNA gene were carried out as described previously (Chun \& Goodfellow, 1995). Identification of phylogenetic neighbours and calculation of pairwise 16S rRNA gene sequence similarities were achieved using the EzTaxon server (http://www.eztaxon. org/; Chun et al., 2007). The novel sequences were aligned with related sequences by using CLUSTAL_X (Thompson et al., 1997); the alignment was refined using PHYDIT (Chun, 1995). Phylogenetic analysis was performed by using the computer packages PHYLIP (Felsenstein, 1993) and PAUP* 4.0 (Swofford, 1998). Phylogenetic trees were inferred using the Fitch-Margoliash (Fitch \& Margoliash, 1967), maximum-likelihood (Felsenstein, 1993), maximum-parsimony (Fitch, 1971) and neighbour-joining (Saitou \& Nei, 1987) algorithms. Distance matrices for the neighbour-joining and Fitch-Margoliash methods were generated according to the model of Jukes \& Cantor (1969). The robustness of the topology in the phylogenetic trees was evaluated by bootstrap analyses (Felsenstein, 1985) of the neighbour-joining method based on 1000 resamplings. The $16 \mathrm{~S}$ rRNA gene sequences of strains WPCB $074^{\mathrm{T}}$ and WPCB165 were continuous stretches of 1453 and $1463 \mathrm{nt}$, respectively. 16S rRNA gene sequence similarity between the two strains was $99.9 \%$; hence, the two strains should be assigned to a single taxon (Fig. 1). Based on 16S rRNA gene sequence similarity data, it was found that the closest relatives of strain $\mathrm{WPCB} 074^{\mathrm{T}}$ were Bacillus solisalsi $\mathrm{YC1}^{\mathrm{T}}(98.4 \%)$, Bacillus barbaricus V2-BIII$\mathrm{A}^{\mathrm{T}}(97.8 \%)$, Bacillus macauensis ZFHKF- ${ }^{\mathrm{T}}$ (96.9\%), Bacillus arsenicus Con $\mathrm{a} / 3^{\mathrm{T}}(96.4 \%)$ and Bacillus gelatini LMG $21880^{\mathrm{T}}$ (95.1\%).

DNA-DNA hybridization was performed by the membrane filter technique using the DIG High Prime DNA Labelling and Detection Starter kit II (Roche Molecular Biochemicals) according to the method described in detail by Lee et al. (2003), with the modification that the hybridization temperature was $45{ }^{\circ} \mathrm{C}$. DNA-DNA relatedness tests were performed between strains $\mathrm{WPCB} 074^{\mathrm{T}}$ and WPCB165 and the type strains of some phylogenetically related Bacillus species. Strains WPCB074 ${ }^{\mathrm{T}}$ and WPCB165 exhibited two independent levels of DNA-DNA relatedness of 96 and $94 \%$. Levels of DNA-DNA relatedness between strain WPCB $074^{\mathrm{T}}$ and the related type strains $B$. solisalsi KCTC $13181^{\mathrm{T}}$, B. barbaricus KACC $12101^{\mathrm{T}}$, B. macauensis

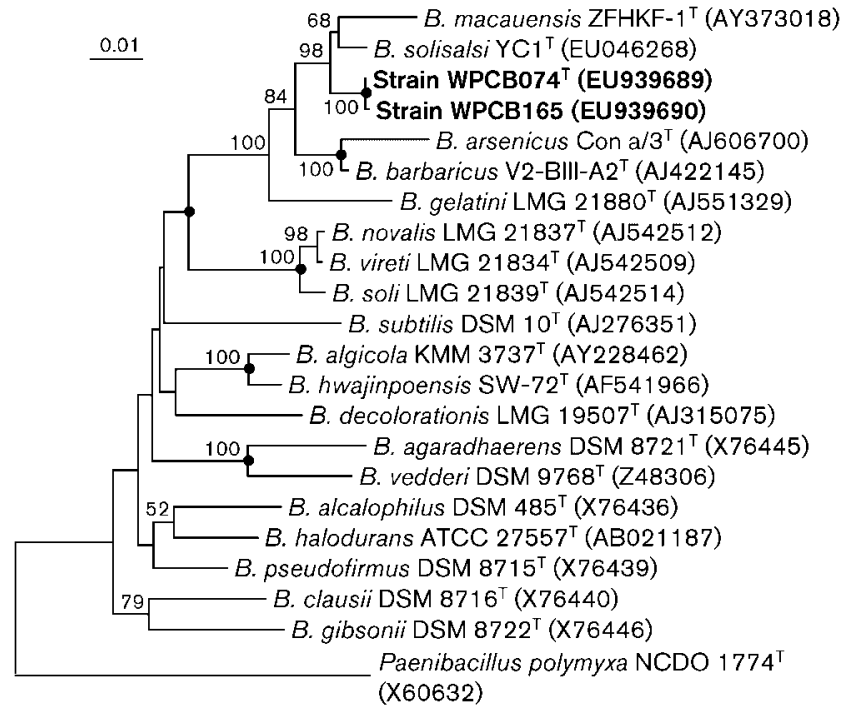

Fig. 1. Neighbour-joining tree based on nearly complete $16 \mathrm{~S}$ rRNA gene sequences showing relationships between strains WPCB074 ${ }^{\top}$ and WPCB165 and some related members of the genus Bacillus. Bootstrap values ( $>50 \% ; 1000$ resamplings) are given at branch points and solid circles indicate that the corresponding nodes (groupings) are also recovered in FitchMargoliash, maximum-parsimony and maximum-likelihood trees. Bar, 0.01 nucleotide substitutions per position.

KACC $12177^{\mathrm{T}}$, B. arsenicus KACC $12116^{\mathrm{T}}$ and B. gelatini KACC $12197^{\mathrm{T}}$ were 26, 17, 20, 14 and $7 \%$, respectively (Supplementary Table S1; available in IJSEM Online). Thus, levels of genetic relatedness according to DNA-DNA hybridization experiments were less than $70 \%$, which leads to the conclusion that strains WPCB074 ${ }^{\mathrm{T}}$ and WPCB165 represent a novel and distinct species (Wayne et al., 1987).

Cells of strains WPCB074 ${ }^{\mathrm{T}}$ and WPCB165 grown on tryptic soy agar (TSA; Becton Dickinson) at $30{ }^{\circ} \mathrm{C}$ for 2 days were used for physiological and biochemical tests. Morphology of the cells was observed using a differential interference microscope (BX50; Olympus) and a scanning electron microscope (S-4800; Hitachi). Endospore formation was observed by phase-contrast microscopy. Motility was examined by observing cells grown in wet mounts using a phase-contrast microscope (TMS-F; Nikon). Growth at various $\mathrm{NaCl}$ concentrations $(0-10 \%, \mathrm{w} / \mathrm{v}$, in increments of $1.0 \%$ ) was investigated in tryptic soy broth (TSB; Becton Dickinson) prepared according to the formula of the Becton Dickinson medium except that no $\mathrm{NaCl}$ was used. The $\mathrm{pH}$ range for growth was determined in TSA that was adjusted to $\mathrm{pH} 4-11$ (in increments of 1 $\mathrm{pH}$ unit) by the addition of $\mathrm{HCl}$ and $\mathrm{NaOH}$. The optimal temperature and temperature range for growth were tested on TSA at $4-50{ }^{\circ} \mathrm{C}$. Anaerobic growth was tested on TSA in a jar containing an AnaeroPak (Mitsubishi Gas Chemical), which works as an oxygen absorber and $\mathrm{CO}_{2}$ generator, for up to 10 days. Catalase and oxidase activities were 
determined using $3 \%$ (v/v) hydrogen peroxide and Kovács' reagent (Kovács, 1956), respectively. Nitrate reduction was tested in TSB containing $0.2 \% \mathrm{KNO}_{3}$ (Skerman, 1967). $\mathrm{H}_{2} \mathrm{~S}$ production was determined on Kligler iron agar (Becton Dickinson). Hydrolysis of CM-cellulose $(1 \%, \mathrm{w} / \mathrm{v})$, casein $(2 \%$ skimmed milk, w/v), egg yolk $(10 \%, w / v)$, starch $(0.2 \%, \mathrm{w} / \mathrm{v})$, Tween $20(1 \%, \mathrm{w} / \mathrm{v})$, Tween $80(1 \%$, $\mathrm{w} / \mathrm{v})$, L-tyrosine $(0.5 \%, \mathrm{w} / \mathrm{v})$ and xylan $(1 \%, \mathrm{w} / \mathrm{v})$ was tested as described by Smibert \& Krieg (1994). DNase activity was determined on DNase test agar (Becton Dickinson). Other biochemical tests and enzymic activities were assessed using API 20NE, API 50CHB, API ZYM kits (bioMérieux) and the GP2 MicroPlate (Biolog) prepared according to the manufacturers' instructions. Antibiotic resistance was determined by the disc diffusion method using commercial antibiotic-impregnated discs (BBL Becton Dickinson). After 5 days of incubation at $30{ }^{\circ} \mathrm{C}$ on TSA, results were interpreted according to the guidelines set forth by the CLSI (2003).

Strains WPCB074 ${ }^{\mathrm{T}}$ and WPCB165 had similar characteristics with respect to their cellular and colonial morphologies. Cells of both strains were Gram-stain-positive, motile rods $(0.5 \mu \mathrm{m}$ wide and $3.0-6.0 \mu \mathrm{m}$ long $)$ and occurred singly or in chains. They produced ellipsoidal endospores that lay in a subterminal position and usually caused the sporangia to swell. Colonies grown on TSA plates for 2 days at $30{ }^{\circ} \mathrm{C}$ were circular, opaque, cream and convex with entire margins and approximately $3-4 \mathrm{~mm}$ in diameter. They did not grow under anaerobic conditions. Both strains grew between 10 and $45{ }^{\circ} \mathrm{C}$, with optimum growth at $20-37{ }^{\circ} \mathrm{C}$. The strains grew at $\mathrm{pH}$ 6-9; optimal growth was observed between $\mathrm{pH} 7$ and 8 . Strains WPCB $074^{\mathrm{T}}$ and WPCB165 grew in $0-9 \%(\mathrm{w} / \mathrm{v}) \mathrm{NaCl}$, with optimal growth at $1-2 \%(\mathrm{w} / \mathrm{v}) \mathrm{NaCl}$. From tests done using the API 20NE system (bioMérieux), both strains gave positive results for oxidase, $\beta$-galactosidase, gelatin hydrolysis, acid production from glucose and assimilation of Dglucose, D-mannose, D-mannitol, $\mathrm{N}$-acetylglucosamine, maltose, potassium gluconate, malic acid and trisodium citrate; negative results were observed for reduction of nitrate to nitrite and to nitrogen, indole production, arginine dihydrolase, urease and assimilation of L-arabinose, capric acid, adipic acid and phenylacetic acid. From tests done using the API 50CHB system (bioMérieux), both strains were positive for acid production from aesculin,

Table 1. Phenotypic characteristics that differentiate strains $\mathrm{WPCB} 074^{\top}$ and WPCB165 from their phylogenetic neighbours in the genus Bacillus

Strains: 1, WPCB074 ${ }^{\mathrm{T}}$; 2, WPCB165; 3, B. arsenicus KACC $12116^{\mathrm{T}}$; 4, B. barbaricus KACC $12101^{\mathrm{T}}$; 5, B. gelatini KACC $12197^{\mathrm{T}}$; 6 , B. macauensis KACC $12177^{\mathrm{T}} ; 7$, B. solisalsi KCTC $13181^{\mathrm{T}}$. Except where indicated, data for reference strains were taken from Zhang et al. (2006), De Clerck et al. (2004), Liu et al. (2009), Shivaji et al. (2005) and Taübel et al. (2003).

\begin{tabular}{|c|c|c|c|c|c|c|c|}
\hline Characteristic & 1 & 2 & 3 & 4 & 5 & 6 & 7 \\
\hline Anaerobic growth & - & - & - & + & - & + & + \\
\hline Motility & + & + & + & - & + & $+^{*}$ & + \\
\hline \multicolumn{8}{|l|}{ Growth at/in: } \\
\hline $15{ }^{\circ} \mathrm{C}$ & + & + & - & - & - & - & + \\
\hline $47^{\circ} \mathrm{C}$ & - & - & - & - & + & - & + \\
\hline $10 \%(\mathrm{w} / \mathrm{v}) \mathrm{NaCl}^{*}$ & - & - & - & - & + & - & + \\
\hline \multicolumn{8}{|l|}{ Hydrolysis of:* } \\
\hline Aesculin & + & + & - & - & + & - & + \\
\hline Gelatin & + & + & + & - & + & + & - \\
\hline Tween 20 & + & + & - & - & - & - & + \\
\hline Tyrosine & - & - & - & - & - & - & + \\
\hline Inulin & - & - & - & - & - & + & + \\
\hline D-Mannitol & + & + & - & - & - & - & + \\
\hline D-Mannose & - & - & - & - & + & - & - \\
\hline Methyl pyruvate & - & - & - & + & - & - & - \\
\hline D-Ribose & + & - & + & - & - & + & - \\
\hline D-Xylose & + & - & - & - & - & - & - \\
\hline DNA G $+C$ content $(\mathrm{mol} \%)$ & 41.9 & 41.4 & 35.0 & $42.0^{*}$ & 41.5 & 40.8 & 41.8 \\
\hline
\end{tabular}

${ }^{\star}$ Data from this study. 
D-fructose, D-glucose, glycogen, maltose, D-mannose, starch, sucrose and trehalose, but negative for the other substrates tested. Neither strain produced $\mathrm{H}_{2} \mathrm{~S}$ or hydrolysed CM-cellulose, egg yolk, Tween 80, L-tyrosine or xylan, but casein, DNA, starch and Tween 20 were hydrolysed by both strains. The detailed results of physiological and biochemical analyses are given in Table 1 and the species description. It is evident from Table 1 that there are several phenotypic characters that readily separate strains WPCB074 ${ }^{\mathrm{T}}$ and WPCB165 from phylogenetically related species.

Cells of strains WPCB074 ${ }^{\mathrm{T}}$ and WPCB165 and reference strains grown on TSA for 1 day at $30{ }^{\circ} \mathrm{C}$ were prepared (in duplicate) and their fatty acid methyl esters were analysed by GLC according to the instructions of the Microbial Identification System (MIDI, 1999). Polar lipids were analysed by using standard procedures (Minnikin et al., 1984). The isomer type of the diamino acid of the cell wall was analysed according to the method of Komagata \& Suzuki (1987). Respiratory quinones were extracted from $300 \mathrm{mg}$ freeze-dried cells, purified according to the method of Minnikin et al. (1984) and analysed by HPLC as described previously (Kroppenstedt, 1985). The G+C content was calculated using the formula described by Mandel et al. (1970). The DNA sample was prepared in duplicate and $\mathrm{G}+\mathrm{C}$ content was determined by the thermal denaturation method of Marmur \& Doty (1962). The cellular fatty acid profiles of strains $\mathrm{WPCB} 074^{\mathrm{T}}$ and WPCB165 revealed the presence of $\mathrm{C}_{14}-\mathrm{C}_{18}$ fatty acids and included mainly iso- and anteiso-branched components. In both strains, iso- $C_{15: 0}$ and anteiso- $C_{15: 0}$ were the major fatty acids. A comparison of cellular fatty acid compositions of strains WPCB074 ${ }^{\mathrm{T}}$ and WPCB165 and type strains of some related species of the genus Bacillus is given in Table 2. The major polar lipids present in both strains were diphosphatidylglycerol, phosphatidylglycerol and phosphatidylethanolamine; minor components were unknown aminolipids, aminophospholipids and a phospholipid. Glycolipids were not detected. The diamino acid in the cell wall peptidoglycan of strains $\mathrm{WPCB} 074^{\mathrm{T}}$ and WPCB165 was meso-diaminopimelic acid. The predominant isoprenoid quinone was unsaturated menaquinone with seven isoprene units (MK-7). The DNA G+C contents of strains WPCB074 ${ }^{\mathrm{T}}$ and WPCB165 were 41.9 and $41.4 \mathrm{~mol} \%$, respectively.

Phylogenetic, genomic, chemotaxonomic and phenotypic data indicate clearly that strains WPCB074 ${ }^{\mathrm{T}}$ and WPCB165 represent a novel genomic species within the genus Bacillus, for which the name Bacillus rigui sp. nov. is proposed.

\section{Description of Bacillus rigui sp. nov.}

Bacillus rigui (ri'gu.i. L. gen. n. rigui of a well-watered place).

Strictly aerobic. Colonies on TSA are circular, opaque, convex, cream coloured and approximately $3-4 \mathrm{~mm}$ in
Table 2. Cellular fatty acid profiles (\%) of strains WPCB $074^{\top}$ and WPCB165 and related species of the genus Bacillus

Strains: 1, WPCB074 ${ }^{\mathrm{T}}$; 2, WPCB165; 3, B. arsenicus KACC $12116^{\mathrm{T}}$; 4, B. barbaricus KACC $12101^{\mathrm{T}}$; 5, B. gelatini KACC $12197^{\mathrm{T}}$; 6 , B. macauensis KACC $12177^{\mathrm{T}}$; 7, B. solisalsi KCTC $13181^{\mathrm{T}}$. All data were obtained in this study; cells of all strains were harvested after cultivation at $30{ }^{\circ} \mathrm{C}$ on TSA medium for 1 day. -, Not detected.

\begin{tabular}{|c|c|c|c|c|c|c|c|}
\hline Fatty acid & 1 & 2 & 3 & 4 & 5 & 6 & 7 \\
\hline \multicolumn{8}{|l|}{ Straight-chain saturated } \\
\hline $\mathrm{C}_{14: 0}$ & 0.8 & 0.8 & 0.8 & 1.1 & 1.3 & 1.2 & 1.3 \\
\hline $\mathrm{C}_{16: 0}$ & 2.3 & 2.0 & 6.9 & 5.7 & 4.7 & 1.4 & 7.2 \\
\hline $\mathrm{C}_{18: 0}$ & - & - & 4.4 & 3.1 & 1.8 & - & 3.2 \\
\hline \multicolumn{8}{|l|}{ Branched } \\
\hline iso- $\mathrm{C}_{14: 0}$ & 4.1 & 4.6 & 2.1 & 5.9 & 1.1 & 4.0 & 6.6 \\
\hline iso- $\mathrm{C}_{15: 0}$ & 27.3 & 30.2 & 28.3 & 35.6 & 44.4 & 34.5 & 11.7 \\
\hline iso- $\mathrm{C}_{15: 1}$ at $12-13$ & - & - & 1.2 & 1.8 & - & - & - \\
\hline iso- $\mathrm{C}_{16: 0}$ & 2.7 & 2.1 & 5.3 & 5.5 & 4.6 & 5.1 & 5.9 \\
\hline iso- $\mathrm{C}_{17: 0}$ & 1.9 & 1.6 & 5.4 & 2.2 & 6.4 & 1.0 & 1.2 \\
\hline iso- $\mathrm{C}_{17: 1} \omega 10 c$ & 0.8 & - & 3.2 & 1.5 & 1.6 & - & - \\
\hline anteiso- $\mathrm{C}_{15: 0}$ & 49.8 & 49.3 & 16.6 & 20.3 & 16.4 & 46.4 & 55.1 \\
\hline anteiso- $\mathrm{C}_{17: 0}$ & 5.0 & 3.9 & 5.3 & 1.6 & 13.2 & 6.5 & 6.7 \\
\hline anteiso- $\mathrm{C}_{17: 1} \mathrm{~A}$ & - & - & 1.6 & 1.3 & - & - & - \\
\hline $\mathrm{C}_{16: 0} \mathrm{~N}$-alcohol & - & - & 0.9 & 1.5 & - & - & - \\
\hline \multicolumn{8}{|l|}{ Monounsaturated } \\
\hline $\mathrm{C}_{16: 1} \omega 7 c$ & 1.7 & 1.7 & 5.2 & 4.6 & 1.0 & - & - \\
\hline $\mathrm{C}_{16: 1} \omega 11 c$ & 1.5 & 1.4 & 4.7 & 2.7 & 1.5 & - & - \\
\hline \multicolumn{8}{|l|}{ Summed features ${ }^{*}$} \\
\hline 3 & - & - & 1.8 & 1.8 & - & - & - \\
\hline 4 & 1.6 & 1.4 & 3.0 & 1.9 & 1.7 & - & - \\
\hline Unknown 14.263 & 0.6 & 1.0 & - & - & - & - & - \\
\hline
\end{tabular}

${ }^{*}$ Summed features represent groups of two or three fatty acids that could not be separated by GLC with the MIDI system. Summed feature 3 contained $\mathrm{C}_{16: 1} \omega 7 c$ and/or iso- $\mathrm{C}_{15: 0}$ 2-OH. Summed feature 4 contained iso- $\mathrm{C}_{17: 1} \mathrm{I}$ and/or anteiso- $\mathrm{C}_{17: 1} \mathrm{~B}$.

diameter after 2 days at $30{ }^{\circ} \mathrm{C}(\mathrm{pH} 7)$. Cells are motile and $0.5 \times 3.0-6.0 \mu \mathrm{m}$ in size. Ellipsoidal endospores are formed in a subterminal position and usually cause sporangia to swell. Growth occurs in $0-9 \%(w / v) ~ \mathrm{NaCl}$ (optimum 1$2 \%$ ), at $\mathrm{pH}$ 6-9 (optimum $\mathrm{pH} 7-8$ ) and at $10-45{ }^{\circ} \mathrm{C}$ (optimum $20-37^{\circ} \mathrm{C}$ ). Oxidase- and catalase-positive. In the API ZYM gallery, alkaline phosphatase, $\alpha$-chymotryp$\sin$, esterase (C4), $\beta$-galactosidase, $\alpha$-glucosidase and leucine arylamidase activities are present; $N$-acetyl- $\beta$ glucosaminidase, acid phosphatase, cystine arylamidase, esterase lipase (C8), $\alpha$-fucosidase, $\alpha$-galactosidase, $\beta$ glucosidase, $\beta$-glucuronidase, lipase (C14), $\alpha$-mannosidase, naphthol-AS-BI-phosphohydrolase, trypsin and valine arylamidase activities are absent. The following carbon sources are utilized (positive with the Biolog GP2 system): adenosine, dextrin, glycerol, D- and L- $\alpha$-glycerol phosphate, $\alpha$-ketovaleric acid, monomethyl succinate, Tween 40 and D-xylose. The remaining substrates of the Biolog GP2 system are not utilized. Cells are sensitive to ( $\mu \mathrm{g}$ per disc, 
unless otherwise indicated): amikacin (30), ampicillin (10), chloramphenicol (30), erythromycin (15), gentamicin (10), kanamycin (30), nalidixic acid (30), penicillin (10 IU), polymyxin B (300 IU), streptomycin (10), tetracycline (30) and vancomycin (30). Other physiological and biochemical characteristics are given in Table 1. The major fatty acids are iso- $\mathrm{C}_{15: 0}$ and anteiso- $\mathrm{C}_{15: 0}$. The major polar lipids are diphosphatidylglycerol, phosphatidylglycerol and phosphatidylethanolamine. The cell wall peptidoglycan contains meso-diaminopimelic acid. The major respiratory quinone is MK-7.

The type strain is WPCB $074^{\mathrm{T}}\left(=\mathrm{KCTC} 13278^{\mathrm{T}}=\mathrm{JCM}\right.$ $16348^{\mathrm{T}}$ ), isolated from fresh water of the Woopo wetland, Republic of Korea. The DNA G + C content of the type strain is 41.9 mol\%. Strain WPCB165 (=KCTC 13279= JCM 16349), isolated from the same source, is a reference strain.

\section{Acknowledgements}

This research was supported by the 21C Frontier Microbial Genomics and Applications Center Program, Ministry of Education, Science \& Technology, Republic of Korea.

\section{References}

Ahmed, l., Yokota, A., Yamazoe, A. \& Fujiwara, T. (2007). Proposal of Lysinibacillus boronitolerans gen. nov., sp. nov., and transfer of Bacillus fusiformis to Lysinibacillus fusiformis comb. nov. and Bacillus sphaericus to Lysinibacillus sphaericus comb. nov. Int J Syst Evol Microbiol 57, 1117-1125.

Albert, R. A., Archambault, J., Lempa, M., Hurst, B., Richardson, C., Gruenloh, S., Duran, M., Worliczek, H. L., Huber, B. E. \& other authors (2007). Proposal of Viridibacillus gen. nov. and reclassification of Bacillus arvi, Bacillus arenosi and Bacillus neidei as Viridibacillus arvi gen. nov., comb. nov., Viridibacillus arenosi comb. nov. and Viridibacillus neidei comb. nov. Int J Syst Evol Microbiol 57, 2729-2737.

Ash, C., Farrow, J. A. E., Wallbanks, S. \& Collins, M. D. (1991). Phylogenetic heterogeneity of the genus Bacillus revealed by comparative analysis of small-subunit-ribosomal RNA sequences. Lett Appl Microbiol 13, 202-206.

Ash, C., Priest, F. G. \& Collins, M. D. (1993). Molecular identification of rRNA group 3 bacilli (Ash, Farrow, Wallbanks and Collins) using a PCR probe test. Proposal for the creation of a new genus Paenibacillus. Antonie van Leeuwenhoek 64, 253-260.

Chun, J. (1995). Computer-assisted classification and identification of actinomycetes. PhD thesis, University of Newcastle, Newcastle, UK.

Chun, J. \& Goodfellow, M. (1995). A phylogenetic analysis of the genus Nocardia with 16S rRNA gene sequences. Int J Syst Bacteriol 45, 240-245.

Chun, J., Lee, J.-H., Jung, Y., Kim, M., Kim, S., Kim, B. K. \& Lim, Y. W. (2007). EzTaxon: a web-based tool for the identification of prokaryotes based on $16 \mathrm{~S}$ ribosomal RNA gene sequences. Int J Syst Evol Microbiol 57, 2259-2261.

Claus, D. \& Berkeley, R. C. W. (1986). Genus Bacillus Cohn 1872. In Bergey's Manual of Systematic Bacteriology, vol. 2, pp. 1105-1140. Edited by P. H. A. Sneath, N. S. Mair, M. E. Sharpe \& J. G. Holt. Baltimore: Williams \& Wilkins.
CLSI (2003). Performance standards for antimicrobial disk susceptibility tests, 8th edn. Approved Standard M2-A8. Wayne, PA: Clinical and Laboratory Standards Institute.

De Clerck, E., Rodríguez-Díaz, M., Vanhoutte, T., Heyrman, J., Logan, N. A. \& De Vos, P. (2004). Anoxybacillus contaminans sp. nov. and Bacillus gelatini sp. nov., isolated from contaminated gelatin batches. Int J Syst Evol Microbiol 54, 941-946.

Felsenstein, J. (1985). Confidence limits on phylogenies: an approach using the bootstrap. Evolution 39, 783-791.

Felsenstein, J. (1993). PHYLIP (phylogeny inference package), version 3.5c. Distributed by the author. Department of Genome Sciences, University of Washington, Seattle, USA.

Fitch, W. M. (1971). Toward defining the course of evolution: minimum change for a specific tree topology. Syst Zool 20, 406-416.

Fitch, W. M. \& Margoliash, E. (1967). Construction of phylogenetic trees. Science 155, 279-284.

Fortina, M. G., Pukall, R., Schumann, P., Mora, D., Parini, C., Manachini, P. L. \& Stackebrandt, E. (2001). Ureibacillus gen. nov., a new genus to accommodate Bacillus thermosphaericus (Andersson et al. 1995), emendation of Ureibacillus thermosphaericus and description of Ureibacillus terrenus sp. nov. Int J Syst Evol Microbiol 51, 447455.

Hatayama, K., Shoun, H., Ueda, Y. \& Nakamura, A. (2006). Tuberibacillus calidus gen. nov., sp. nov., isolated from a compost pile and reclassification of Bacillus naganoensis Tomimura et al. 1990 as Pullulanibacillus naganoensis gen. nov., comb. nov. and Bacillus laevolacticus Andersch et al. 1994 as Sporolactobacillus laevolacticus comb. nov. Int J Syst Evol Microbiol 56, 2545-2551.

Heyndrickx, M., Lebbe, L., Kersters, K., De Vos, P., Forsyth, G. \& Logan, N. A. (1998). Virgibacillus: a new genus to accommodate Bacillus pantothenticus (Proom and Knight 1950). Emended description of Virgibacillus pantothenticus. Int J Syst Bacteriol 48, 99106.

Jeon, C. O., Lim, J. M., Lee, J. M., Xu, L. H., Jiang, C. L. \& Kim, C. J. (2005). Reclassification of Bacillus haloalkaliphilus Fritze 1996 as Alkalibacillus haloalkaliphilus gen. nov., comb. nov. and the description of Alkalibacillus salilacus sp. nov., a novel halophilic bacterium isolated from a salt lake in China. Int J Syst Evol Microbiol 55, 1891-1896.

Jukes, T. H. \& Cantor, C. R. (1969). Evolution of protein molecules. In Mammalian Protein Metabolism, vol. 3, pp. 21-132. Edited by H. N. Munro. New York: Academic Press.

Komagata, K. \& Suzuki, K. (1987). Lipid and cell-wall analysis in bacterial systematics. Methods Microbiol 19, 161-207.

Kovács, N. (1956). Identification of Pseudomonas pyocyanea by the oxidase reaction. Nature 178, 703.

Kroppenstedt, R. M. (1985). Fatty acid and menaquinone analysis of actinomycetes and related organisms. In Chemical Methods in Bacterial Systematics (Society for Applied Bacteriology Technical Series vol. 20), pp. 173-199. Edited by M. Goodfellow \& D. E. Minnikin. New York: Academic Press.

Lee, J.-S., Lee, K. C., Pyun, Y.-R. \& Bae, K. S. (2003). Arthrobacter koreensis sp. nov., a novel alkalitolerant bacterium from soil. Int J Syst Evol Microbiol 53, 1277-1280.

Liu, H., Zhou, Y., Liu, R., Zhang, K.-Y. \& Lai, R. (2009). Bacillus solisalsi sp. nov., a halotolerant, alkaliphilic bacterium isolated from soil around a salt lake. Int J Syst Evol Microbiol 59, 1460-1464.

Mandel, M., Igambi, L., Bergendahl, J., Dodson, M. L. \& Scheltgen, E. (1970). Correlation of melting temperature and cesium chloride buoyant density of bacterial deoxyribonucleic acid. J Bacteriol 101, 333-338. 
Marmur, J. \& Doty, P. (1962). Determination of the base composition of deoxyribonucleic acid from its thermal denaturation temperature. J Mol Biol 5, 109-118.

MIDI (1999). Sherlock Microbial Identification System Operating Manual, version 3.0. Newark, DE: MIDI, Inc.

Minnikin, D. E., O’Donnell, A. G., Goodfellow, M., Alderson, G., Athalye, M., Schaal, A. \& Parlett, J. H. (1984). An integrated procedure for the extraction of bacterial isoprenoid quinones and polar lipids. J Microbiol Methods 2, 233-241.

Nakamura, L. K. (1996). Paenibacillus apiarius sp. nov. Int J Syst Bacteriol 46, 688-693.

Nazina, T. N., Tourova, T. P., Poltaraus, A. B., Novikova, E. V., Grigoryan, A. A., Ivanova, A. E., Lysenko, A. M., Petrunyaka, V. V., Osipov, G. A. \& other authors (2001). Taxonomic study of aerobic thermophilic bacilli: descriptions of Geobacillus subterraneus gen. nov., sp. nov. and Geobacillus uzenensis sp. nov. from petroleum reservoirs and transfer of Bacillus stearothermophilus, Bacillus thermocatenulatus, Bacillus thermoleovorans, Bacillus kaustophilus, Bacillus thermoglucosidasius and Bacillus thermodenitrificans to Geobacillus as the new combinations G. stearothermophilus, G. thermocatenulatus, G. thermoleovorans, G. kaustophilus, G. thermoglucosidasius and G. thermodenitrificans. Int J Syst Evol Microbiol 51, 433-446.

Priest, F. G., Goodfellow, M. \& Todd, C. (1981). The genus Bacillus: a numerical analysis. In The Aerobic Endospore-forming Bacteria: Classification and Identification (Society for General Microbiology Special Publication, vol. 4), pp. 91-103. Edited by R. C. W. Berkeley \& M. Goodfellow. London: Academic Press.

Saitou, N. \& Nei, M. (1987). The neighbor-joining method: a new method for reconstructing phylogenetic trees. Mol Biol Evol 4, 406425.

Shida, O., Takagi, H., Kadowaki, K. \& Komagata, K. (1996). Proposal for two new genera, Brevibacillus gen. nov. and Aneurinibacillus gen. nov. Int J Syst Bacteriol 46, 939-946.

Shida, O., Takagi, H., Kadowaki, K., Nakamura, L. K. \& Komagata, K. (1997a). Emended description of Paenibacillus amylolyticus and description of Paenibacillus illinoisensis sp. nov. and Paenibacillus chibensis sp. nov. Int J Syst Bacteriol 47, 299-306.

Shida, O., Takagi, H., Kadowaki, K., Nakamura, L. K. \& Komagata, K. (1997b). Transfer of Bacillus alginolyticus, Bacillus chondroitinus, Bacillus curdlanolyticus, Bacillus glucanolyticus, Bacillus kobensis, and Bacillus thiaminolyticus to the genus Paenibacillus and emended description of the genus Paenibacillus. Int J Syst Bacteriol 47, 289-298.

Shivaji, S., Suresh, K., Chaturvedi, P., Dube, S. \& Sengupta, S. (2005). Bacillus arsenicus sp. nov., an arsenic-resistant bacterium isolated from a siderite concretion in West Bengal, India. Int J Syst Evol Microbiol 55, 1123-1127.

Skerman, V. B. D. (1967). A Guide to the Identification of the Genera of Bacteria, 2nd edn. Baltimore: Williams \& Wilkins.

Slepecky, R. \& Hemphill, E. (1992). The genus Bacillus - nonmedical. In The Prokaryotes, 2nd edn, pp. 1663-1696. Edited by A. Balows, H. G. Trüper, M. Dworkin, W. Harder \& K. H. Schleifer. New York: Springer.

Smibert, R. M. \& Krieg, N. R. (1994). Phenotypic characterization. In Methods for General and Molecular Bacteriology, pp. 607-654. Edited by P. Gerhardt, R. G. E. Murray, W. A. Wood \& N. R. Krieg. Washington, DC: American Society for Microbiology.

Stackebrandt, E. \& Liesack, W. (1993). Nucleic acids and classification. In Handbook of New Bacterial Systematics, pp. 152-189. Edited by M. Goodfellow \& A. G. O’Donnell. London: Academic Press.
Staley, J. T. (1968). Prosthecomicrobium and Ancalomicrobium, new prosthecate freshwater bacteria. J Bacteriol 95, 1921-1944.

Swofford, D. L. (1998). Phylogenetic analysis using parsimony (PAUP), version 4. Sunderland, MA: Sinauer Associates.

Taübel, M., Kämpfer, P., Buczolits, S., Lubitz, W. \& Busse, H.-J. (2003). Bacillus barbaricus sp. nov., isolated from an experimental wall painting. Int J Syst Evol Microbiol 53, 725-730.

Tcherpakov, M., Ben-Jacob, E. \& Gutnick, D. L. (1999). Paenibacillus dendritiformis sp. nov., proposal for a new pattern-forming species and its localization within a phylogenetic cluster. Int J Syst Bacteriol 49, 239-246.

Thompson, J. D., Gibson, T. J., Plewniak, F., Jeanmougin, F. \& Higgins, D. G. (1997). The CLUSTAL_X windows interface: flexible strategies for multiple sequence alignment aided by quality analysis tools. Nucleic Acids Res 25, 4876-4882.

Vaishampayan, P., Miyashita, M., Ohnishi, A., Satomi, M., Rooney, A., La Duc, M. T. \& Venkateswaran, K. (2009). Description of Rummeliibacillus stabekisii gen. nov., sp. nov. and reclassification of Bacillus pycnus Nakamura et al. 2002 as Rummeliibacillus pycnus comb. nov. Int J Syst Evol Microbiol 59, 1094-1099.

Wainø, M., Tindall, B. J., Schumann, P. \& Ingvorsen, K. (1999). Gracilibacillus gen. nov., with description of Gracilibacillus halotolerans gen. nov., sp. nov.; transfer of Bacillus dipsosauri to Gracilibacillus dipsosauri comb. nov., and Bacillus salexigens to the genus Salibacillus gen. nov., as Salibacillus salexigens comb. nov. Int J Syst Bacteriol 49, 821-831.

Wayne, L. G., Brenner, D. J., Colwell, R. R., Grimont, P. A. D., Kandler, O., Krichevsky, M. I., Moore, L. H., Moore, W. E. C., Murray, R. G. E. \& other authors (1987). International Committee on Systematic Bacteriology. Report of the ad hoc committee on reconciliation of approaches to bacterial systematics. Int J Syst Bacteriol 37, 463-464.

Wisotzkey, J. D., Jurtshuk, P., Jr, Fox, G. E., Deinhard, G. \& Poralla, K. (1992). Comparative sequence analysis on the $16 \mathrm{~S}$ rRNA (rDNA) of Bacillus acidocaldarius, Bacillus acidoterrestris, and Bacillus cycloheptanicus and proposal for creation of a new genus, Alicyclobacillus gen. nov. Int J Syst Bacteriol 42, 263-269.

Yoon, J.-H., Yim, D. K., Lee, J.-S., Shin, K.-S., Sato, H. H., Lee, S. T., Park, Y. K. \& Park, Y.-H. (1998). Paenibacillus campinasensis sp. nov., a cyclodextrin-producing bacterium isolated in Brazil. Int $J$ Syst Bacteriol 48, 833-837.

Yoon, J. H., Lee, K. C., Weiss, N., Kho, Y. H., Kang, K. H. \& Park, Y. H. (2001a). Sporosarcina aquimarina sp. nov., a bacterium isolated from seawater in Korea, and transfer of Bacillus globisporus (Larkin and Stokes 1967), Bacillus psychrophilus (Nakamura 1984) and Bacillus pasteurii (Chester 1898) to the genus Sporosarcina as Sporosarcina globispora comb. nov., Sporosarcina psychrophila comb. nov. and Sporosarcina pasteurii comb. nov., and emended description of the genus Sporosarcina. Int J Syst Evol Microbiol 51, 1079-1086.

Yoon, J.-H., Weiss, N., Lee, K.-C., Lee, I.-S., Kang, K. H. \& Park, Y.-H. (2001b). Jeotgalibacillus alimentarius gen. nov., sp. nov., a novel bacterium isolated from jeotgal with L-lysine in the cell wall, and reclassification of Bacillus marinus Rüger 1983 as Marinibacillus marinus gen. nov., comb. nov. Int J Syst Evol Microbiol 51, 2087-2093.

Yoon, J. H., Kang, S. J. \& Oh, T. K. (2007). Reclassification of Marinococcus albus Hao et al. 1985 as Salimicrobium album gen. nov., comb. nov. and Bacillus halophilus Ventosa et al. 1990 as Salimicrobium halophilum comb. nov., and description of Salimicrobium luteum sp. nov. Int J Syst Evol Microbiol 57, 2406-2411.

Zhang, T., Fan, X., Hanada, S., Kamagata, Y. \& Fang, H. H. P. (2006). Bacillus macauensis sp. nov., a long-chain bacterium isolated from a drinking water supply. Int J Syst Evol Microbiol 56, 349-353. 